\title{
The Effect of Implementing Student Team Achievement Division (STAD) Learning Model on Improving the Science Learning Achievement of Children with Emotional and Social Disorders
}

\author{
Serla Kusuma Arum; Sunardi; Herry Widyastono \\ Sebelas Maret University, Surakarta, Indonesia \\ http://dx.doi.org/10.18415/ijmmu.v8i12.3190
}

\begin{abstract}
This study aims to determine the effect of the student team achievement division (STAD) learning model in improving the science learning achievement of class XI students of SLB E Bhina Putera Surakarta Indonesia in the 2020/2021 academic year. This research is an experimental research that uses a one group pretest-posttest design. The subjects in this study were 5 emotional and social disorders children in class XI at SLB E Bhina Putera Surakarta in the 2020/2021 academic year which were determined using the saturated sampling technique. The research instrument used a written test in the form of multiple choice totaling 25 questions. The results of this study were analyzed by using the Wilcoxon Sign Rank Test. Based on the data analysis that has been conducted, it found that the $\mathrm{Z}_{\text {count }}$ value $=-2.060$ with Asymp. Sig. (2-tailed) of 0.039 which is at the significance level $(p<0.05)$. Based on the results that have been obtained, it shows that the student team achievement division (STAD) learning model has an effect on increasing the science learning achievement of class XI students with SLB E Bhina Putera Surakarta in the 2020/2021 academic year.
\end{abstract}

Keywords: Student Team Achievement Division (STAD) Learning Model; Children with Emotional and Social Disorders; Science Learning Achievement

\section{Introduction}

Education has a very important role in developing the quality of the nation. Improving the quality and efficiency of education management through planned, directed and sustainable education reform is important in facing challenges in accordance with the demands of changing life so that it needs to be conducted. Education for all citizens is a right that must be given by the state, including children with special needs. Children with special needs are children who deviate from the average normal child in terms of mental characteristics, sensory, physical, neuromuscular, social and emotional behavior, communication skills, or a combination of two or more disorders. Therefore, they require modification of school assignments, learning methods or educational services in developing their potential or abilities to the fullest (Pratiwi, 2011: 3-4). Regarding the classification of children with special needs, Choiri and Yusuf (2009: 8) suggested the classification of children with special needs as follows: blind children, deaf children, mentally retarded children, children with disabilities, children with emotional and social 
disorders, children with learning difficulties, children with behavioral disorders, gifted children, autistic children, and slow learners.

One of the children with special needs who need special education services is a emotional and social disorders child. Somantri (2007: 139) explains that emotional and social disorders children are children who experience emotional and behavioral disturbances or barriers, so they are less able to adapt well to the family, school and public. Sometimes children with emotional and social disorders's behavior do not reflect maturity and likes to withdraw from the environment. Thus, they harm themselves and others. According to Mudjito (2012: 16) emotional and social disorders children have characteristics that tend to be rebellious, easily aroused by their emotions (emotional and irritable), often take aggressive, destructive, disruptive action, often act in violation of social norms, moral norms, legal norms, and tend to have low academic achievement and motivation, often skipping class. Based on this understanding, emotional and social disorders children are children who experience obstacles or disturbances in terms of controlling their emotions and difficulties in socializing with the community and their environment in a natural and normal manner so that they often harm themselves.

Based on previous study in class XI of SLB E Bhina Putera Surakarta for the 2020/2021 academic year, there are several problems that appear in class XI such as children are irritable, leave class during class hours, and often skip the class which has an impact on children's low learning achievement, especially in science subjects. This is proved by the results of the science test given showing a lower number than the passing grade applied at SLB E Bhina Putera Surakarta.

Yumarlin (2013: 75) argues that science subjects are expected to be a vehicle for students to learn about themselves and the natural surroundings, as well as further development to be applied in daily life. Science learning is very important for students as background knowledge to know all the ecosystems that exist in the world regarding the surrounding nature to its roots, as well as representing knowledge of living things such as humans, animals, plants and other living beings. The low science learning achievement of children with special needs indicates that children lack knowledge acquisition related to living things and the course of life in science principles.

One of the causes of the low science learning achievement of children with emotional and social disorders is the learning process that has not used learning models that can motivate, foster creativity, self-confidence, cooperation and fun that are adapted to the characteristics of children with emotional and social disorders. One of the learning models that can be used as an alternative solution is the student achievement division (STAD) learning model. According to Slavin in Isjoni (2013: 17), the essence of the STAD model is that the teacher delivers a material then the students join in groups consisting of several people who are a mixture based on the level of achievement, gender and ethnicity to solve the questions given by the teacher and ensure that all team members have mastered the lesson. After that, the students submit the work of each group to the teacher. The team that gets the highest score gets an award then all the children are given a quiz about the material.

The Student Teams Achievement Divisions (STAD) learning model is not the same as just learning in groups. The basic elements of this learning model are important things that distinguish it from the division of groups that are conducted at random. Implementing the STAD learning model procedures correctly will enable the class to run effectively. In addition, children will become more active in learning because they will always interact with other friends in doing assignments and in conducting experiments that are very necessary in improving their learning achievement, especially science learning achievement.

Based on these conditions, it is necessary to conduct research to determine the effect of implementing the Student Teams Achievement Divisions (STAD) learning model on improving the learning achievement of class XI children at SLB E Bhina Putera Surakarta for the 2020/2021 academic year.

The Effect of Implementing Student Team Achievement Division (STAD) Learning Model on Improving the Science Learning Achievement of Children with Emotional and Social Disorders 


\section{Research Method}

The research was conducted at SLB E Bhina Putera Surakarta. The subjects in this study were 5 emotional and social disorders children in class XI who were determined using the saturated sampling technique. This research is quantitative research with an experimental method. Wiersma in Emzir (2017: 63) defines an experiment as a research situation that consists of at least one independent variable, called an experimental variable, deliberately manipulated by the researcher. The research design used in this study was a one-group pretest-posttest design. Arikunto (2006: 78) stated that one-group pretest-posttest design is research conducted twice that is before the experiment (pretest) and after the experiment (posttest) with one group of subjects. According to Arikunto in Widoyoko (2012: 17), data is defined as the result of recording researchers, either in the form of facts or figures. The data collection technique in this study used a written test in the form of multiple choices with a total of 25 questions. The data analysis technique in this study used non-parametric analysis of the Wilcoxon-marked ranking test.

\section{Research Result}

Based on the tests conducted before the treatment (pretest) and after the treatment (posttest), the following data were obtained.

Table 1. Values of pretest and posttest

\begin{tabular}{|c|c|c|c|}
\hline No & Students' Name (Initial) & Pretest & Posttest \\
\hline 1. & Kahinur & 24 & 72 \\
\hline 2. & Mona & 40 & 76 \\
\hline 3. & Adit & 28 & 64 \\
\hline 4. & Anis & 40 & 80 \\
\hline 5. & Annisa & 20 & 56 \\
\hline & Average & 30,4 & 69,6 \\
\hline
\end{tabular}

Table 2. Calculation of Wilcoxon Signed Ranks Test data analysis

\section{Ranks}

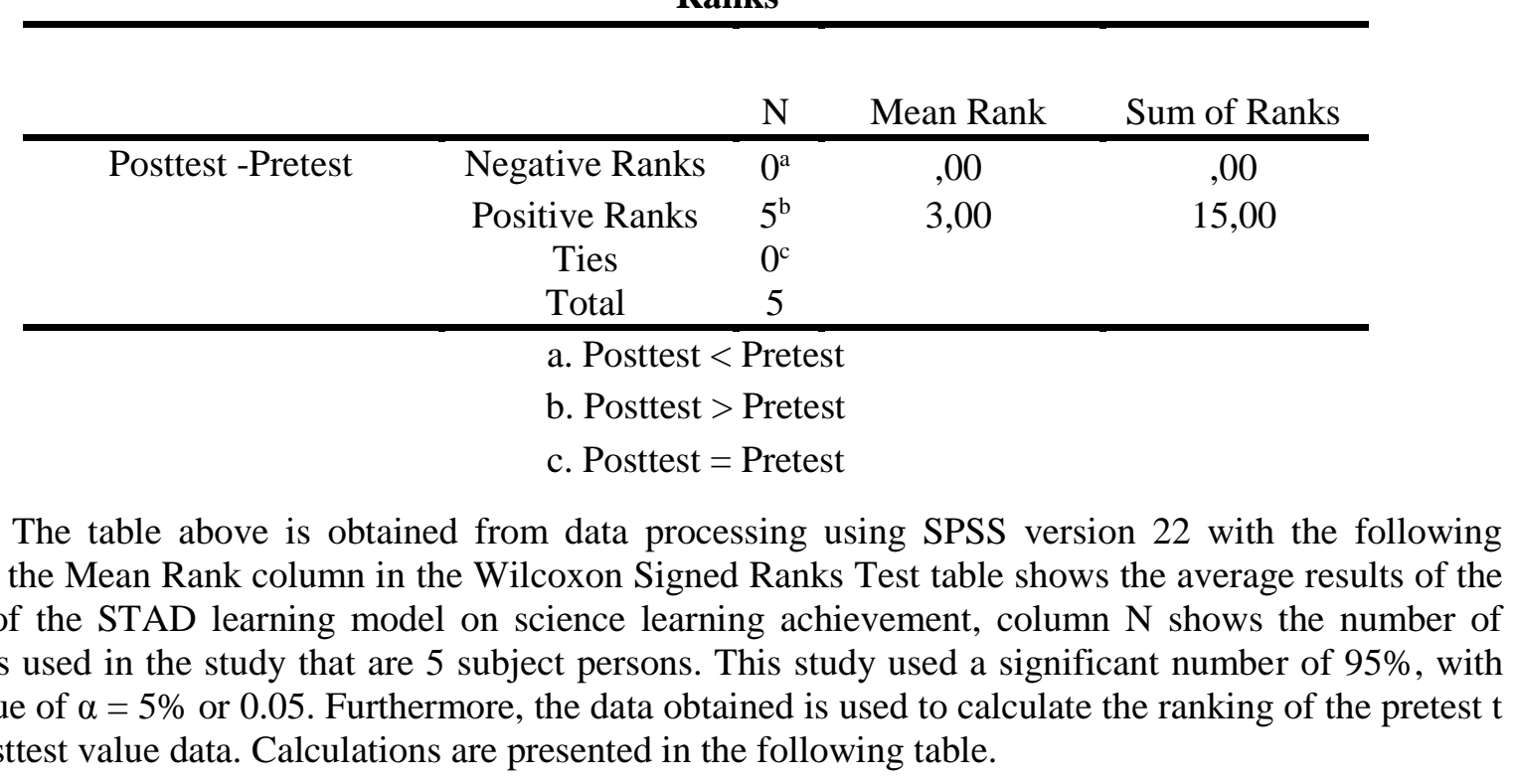

The Effect of Implementing Student Team Achievement Division (STAD) Learning Model on Improving the Science Learning Achievement of Children with Emotional and Social Disorders 
Table 3. Statistic Test Result.

Test Statistics ${ }^{\mathrm{a}}$

Posttest - Pretest

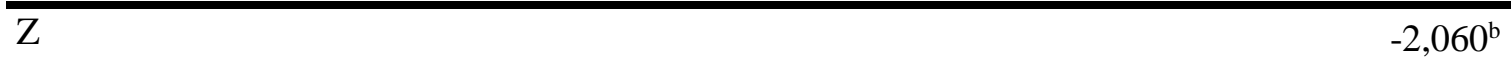

Asymp. Sig. (2-tailed)

a. Wilcoxon Signed Ranks Test

b. Based on negative ranks.

Based on the table above, it shows the value of the Wilcoxon Signed Ranks Test $(Z)$ of -2.060 and Asymp.Sig. (2-tailed) $=0.039$ with a significance level $(\alpha)$ of 0.05 . Asymp.Sig value. (2-tailed) $=$ $0.039<\alpha=0.05$ then Ho is rejected and Ha is accepted. Therefore, it can be concluded that the use of the STAD learning model has an effect on increasing the science learning achievement of class XI emotional and social disorders children at SLB E Bhina Putera Surakarta in the 2020/2021 academic year.

\section{Discussion}

The conducted research found that by using the student teams achievement division (STAD) learning model has proven to have an effect on increasing the science learning achievement of class XI students of SLB E Bhina Putera Surakarta in the 2020/2021 academic year. The student teams achievement division (STAD) learning model can make it easier for students to learn, especially science lessons on the human digestive system, so that it has the effect of increasing children's science learning achievement after being given treatment using the student teams achievement division (STAD) learning model, with a pretest score of 30.4 which increased to 69.6 at the posttest.

Children with emotional and social disorders have their own characteristics that make their learning achievement low. Hallahan and Kauffman in Mahhabati (2010: 57) stated that children with emotional disturbances and difficult behavior are usually lacking in the ability to read basic skills and math because disturbance of emotions and behaviors destruct their attention in receiving lessons when attention is a factor important in the learning process. Majid (2013: 185) suggests that the Student Teams Achievement Divisions (STAD) learning model in its application consists of five main components as follows: class presentations, team learning, individual tests, individual development scores, and team awards. In the STAD learning model, there are 3 discussions of material through the teacher and the children themselves in the form of discussions and presentations as well as individual tests to determine group scores. This will make the emotional and social disorders child not easily lose his attention in learning because he will be required to focus on the material provided in order to be able to answer questions on individual questions that determine the group's score later.

Furthermore, emotional and social disorders children are often angry, sleeping in class, skipping class, going out of class so that it makes children's learning achievement low. This situation is caused by children with emotional and social disorders who have difficulty socializing with their classmates. Slavin in Isjoni (2013: 17) stated that the STAD learning model is learning that emphasizes the activities and interactions of children to work together and motivate each other in mastering the subject matter in order to achieve maximum achievement. The learning situation using the STAD learning model is designed to make students mutually motivated and work well together.

The Effect of Implementing Student Team Achievement Division (STAD) Learning Model on Improving the Science Learning Achievement of Children with Emotional and Social Disorders 
The learning process in the STAD learning model also makes children more responsible. In the group, the child has the responsibility to determine the score obtained from the group through individual tests. So that children will concentrate and try to understand the material in order to give the best score for the group.

\section{Conclusion and Suggestions}

Based on the results of research that has been conducted by researchers, it can be concluded that the student team achievement division (STAD) learning model can improve the learning achievement of science learning for children with emotional and social disorders in class XI SLB E Bhina Putera Surakarta in the 2020/2021 academic year.

Suggestions from the researcher: Subjects are limited to 5 children, so the researcher recommends the next researcher to take a wider sample in order to get a better result of measuring the effect of the student team achievement division (STAD) learning model in learning.

\section{Bibliography}

Arikunto, S. (2006). Prosedur Penelitian Suatu Pendekatan Praktik. Jakarta: Rineka Cipta.

Coiri,A.S\& Yusuf,M.(2009). Pendidikan Anak Berkebutuhan Khusus Secara Inklusif. Surakarta: Inti Media Surakarta.

Emzir. (2017). Metodologi Penelitian Pendidikan: Kuantitatif dan Kualitatif. Depok: Rajawali Pers.

Isjoni.(2013). Cooperative Learning Mengembangkan Kemampuan Belajar Berkelompok. Bandung: Alfabeta.

Iskandar, S. (2001). Pendidikan Ilmu Pengetahuan Alam. Yogyakarta : Pustaka Pelajar.

Mahhabati,A. (2010). Pendidikan Inklusif Untuk Anak dengan Gangguan Emosi dan Perilaku Tunalaras. Jurnal Pendidikan Inklusi. Vol 7. 2. 1-10.

Majid, A. (2013). Strategi Pembelajaran. Bandung : PT Remaja Rosdakarya.

Mudjito, H.E. (2012). Pendidikan Inklusi. Jakarta: Baduose Media Jakarta.

Pratiwi, MM. S. (2011). Psikologi Anak Berkebutuhan Khusus. Semarang: Semarang University Press

Somatri, Sutjihati. (1996). Psikologi anak luar biasa. Bandung: Refika Aditama.

Yumarlin MZ. (2013). Pengembangan Permainan Ular Tangga untuk Kuis Mata Pelajaran Sains Sekolah Dasar. Jurnal Teknik. Vol.3. No.1.1-10.

\section{Copyrights}

Copyright for this article is retained by the author(s), with first publication rights granted to the journal.

This is an open-access article distributed under the terms and conditions of the Creative Commons Attribution license (http://creativecommons.org/licenses/by/4.0/). 